\title{
DOKUMENTÁCIA ZANIKNUTÝCH CIEST V KATASTRI OBCÍ SVRČINOVEC, ČIERNE A SKALITÉ. NÁČRT PROBLEMATIKY KOPANIČIARSKEJ KOLONIZÁCIE NA ÚZEMÍ SEVERNÝCH KYSÚC
}

\author{
MAREK VOJTEČEK - ADRIÁN NEMERGUT
}

\begin{abstract}
Abstrakt: Ciel'om predloženého príspevku bola dokumentácia zaniknutých cestných reliktov na trase stavby dialnice D3 Svrčinovec - Skalité, analýza ich tvarov a interpretácia v kultúrno-historickom kontexte. Hornatý a zalesnený terén krajiny severných Kysúc pozitivne vplýval na zachovanie charakteristických reliktov zaniknutých ciest. Devätnást' dokumentovaných reliktov predstavuje doposial' najväčši preskúmaný ucelený súbor na územi Slovenska. Cesty mali lokálny charakter a súviseli s kopaničiarskou kolonizáciou v 17. storoči. Pri zakladaní kopaničiarskych osád sa ich vymedzený chotár rozdelil na presné usadlosti. Hranice usadlostí (zárubkov) vymedzovali zárubkové cesty. Cesty na jednej strane tvorili hranicu jednotlivých zárubkov, na strane druhej zabezpečovali pohyb a transport materiálu medzi dvorom a extravilánom usadlosti.
\end{abstract}

Kl'účové slová: Kysuce - cesty - novovek-kopaničiarska kolonizácia.

Documentation of Defunct Roads in the Cadastral Zone of the Svrčinovec, Čierne and Skalité Villages. Outline of the colonization of mountain areas in the territory of north Kysuce

Abstract: The objective of this paper is the documentation of the relics of defunct roads on the route of the D3 Svrčinovec-Skalité motorway, the analysis of their courses and their interpretation in the cultural and historical context. The hilly and forested landscape of north Kysuce had a positive influence on the preservation of the characteristic relics of defunct roads. 19 documented relics present the largest series investigated in Slovak territory so far. The roads had a local character and were related to the colonization of mountain areas in the 17th century. During the establishment of mountain settlements, the particular area was divided into individual homesteads. The limits of the homesteads were demarcated by roads. The roads thus made up the borders of the individual homesteads, while on the other hand they also served traffic and transport of material between the homesteads and their surroundings.

Key words: Kysuce - roads - modern age - colonization of mountain areas.

\section{Úvod}

Výskum zaniknutých cestných reliktov nemá na Slovensku takú dlhú tradíciu ako v okolitých krajinách. Súhrnný stav bádania podal M. Slivka (1998), podl’a ktorého je zrejmé, že výskum bol zameraný skôr na historické cesty a ich dial'kové trasy. Výnimku tvorili prieskumné práce F. Javorského $(1978,104,105,113)$ a M. Slivku $(1990,105)$, ktorí venovali pozornost' reliktom zaniknutých ciest v teréne. Až v posledných rokoch sa aj pod vplyvom trendov zo susedných krajín (Bolina 2004; Bolina-Cendelín 2011; Cendelín-Bolina-Adam 2010; Martínek a kol. 2013; Severin 2001; Sadowska-Topór 1999) výskum zameriava na podrobné prieskumy reliktov v menších, uzavretých regiónoch (Pažinová-Beljak-Slámová-Beláček 2013). Rámcovou rekonštrukciou stredovekej a novovekej cestnej siete v žilinskom a kysuckom regióne, ktorá je spojená s vyhl'adávaním konkrétnych terénnych reliktov, sa vo svojej diplomovej práci zaoberal M. Vojteček (2007).

Základným ciel’om príspevku bola dokumentácia priebehu zaniknutých cestných reliktov na trase stavby D3 Svrčinovec - Skalité a jej širšieho okolia, analýza ich tvarov v priečnom a pozdĺžnom profile a ich interpretácia v kultúrno-historickom kontexte.

Prieskumy a dokumentácia zaniknutých ciest boli podmienené záchranným archeologickým výskumom na stavbe dial'nice D3. Aj napriek tomu, že prieskumy prebiehali iba v priestore a najbližšom zázemí trasy stavby, sledovaný výrez krajiny bol dostatočný na zachytenie reprezentatívnych situácií. Už počas prípravných prieskumných prác bolo zretel'né pravidelné rozloženie cestných reliktov, ktoré mali zjavne lokálny charakter a celý ich priebeh sa nachádzal v jednom katastri. Ide o prvý krok projektu, náčrtu možnosti rekonštrukcie tradičnej kultúrnej krajiny v horských oblastiach severných Kysúc, pričom výsledky je nutné považovat' za predbežné. 
Trasa budúcej dial’nice viedla krajinou severných Kysúc, ktorá je charakteristická územím silne členitých vrchovín. Z toho vyplýva výrazná sklonitost’ územia s častým výskytom zosuvov. Z geologického hladiska priestor spadá do flyšového pásma v oblasti kontaktu Jablunkovského medzihoria a Kysuckých Beskýd. Zóna obsahuje najmä usadené horniny pieskovcov a ílovcov s obmedzenou priepustnostou vody. Obce Svrčinovec, Čierne a Skalité sa rozprestierajú v údolí Skalitanky a Čierňanky, ktoré je z obidvoch strán obklopené vrchmi Jablunkovského medzihoria a vytvára koridor orientovaný v smere východ-západ v slovensko-sliezsko-pol'skom pohraničí (obr. 1). Charakter krajiny a neinvazívne pol'nohospodárske postupy v 20. storočí sa pozitívne odzrkadlili v stave zachovania tradičnej kultúrnej krajiny, ktorá sa v tomto priestore formovala od polovice 17. storočia.

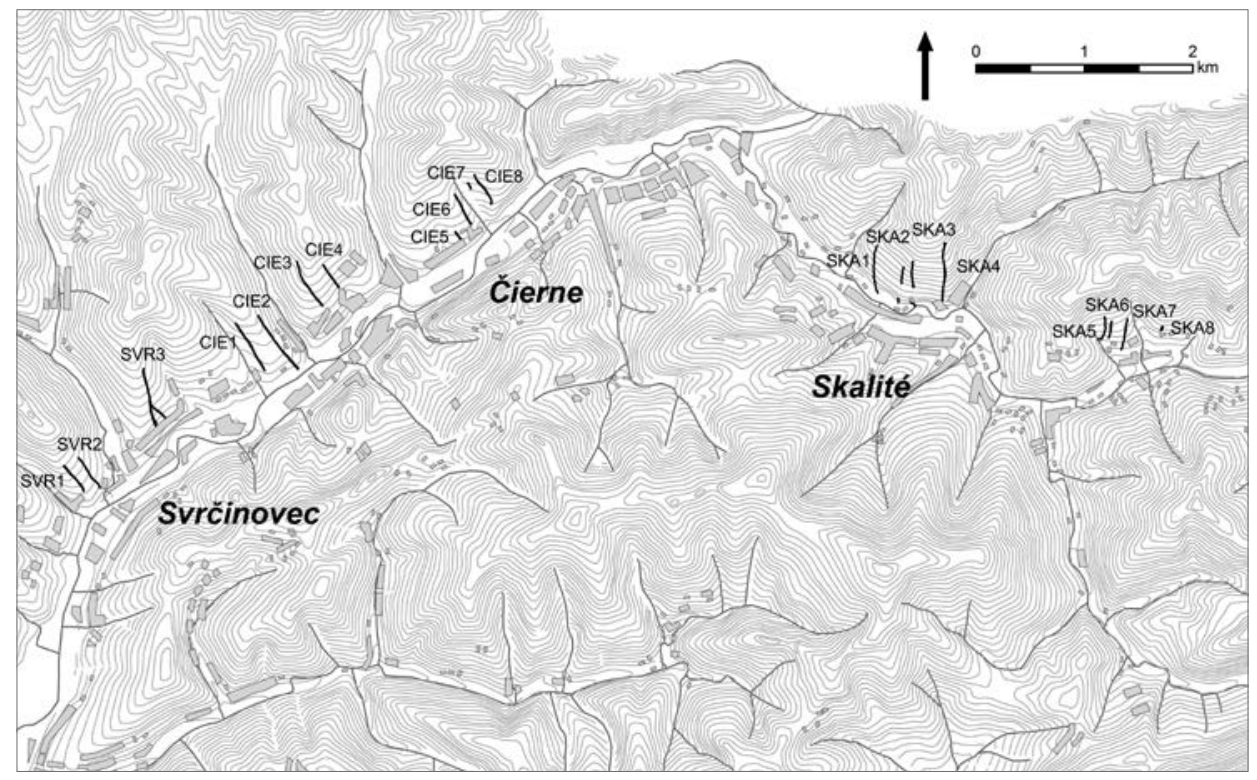

Obr. 1. Mapa sledovaného územia s preskúmanými reliktami ciest.

Abb. 1. Karte des beobachteten Gebietes mit untersuchten Wegerelikten.

\section{Historické pozadie}

Územie severných Kysúc bolo osídl’ované relatívne neskoro. Obec Svrčinovec bola založená kolonizáciou na valašskom práve začiatkom 17. storočia. Prvá písomná správa pochádza z roku 1613. Čierne a Skalité boli založené v prvej polovici 17. storočia neskoršou kopaničiarskou kolonizáciou. Dedina Čierne je v písomnostiach prvýkrát spomenutá v roku 1638 a Skalité v roku 1641 (Krško-Velička 2011, 23). Chotáre troch hornokysuckých obcí boli poznačené opakovanými majetkovými a pohraničnými spormi, ktoré pretrvávali až do konca 18. storočia. Na túto oblast' si robili nároky uhorské panstvá Budatínskeho a Strečnianskeho hradu. Rovnako sú v písomných prameňoch doložené časté pohraničné spory vo forme prepadov a rabovania dedín zo strany Těšínskeho kniežatstva (Paráčová 2008, 10, 11). Pred vznikom týchto obcí, v 16. storočí, patrilo ich územie do chotára Krásna nad Kysucou a bolo sporadicky osídlené valachmi (Beňko 1985, 32). Valašské obyvatel'stvo bolo mobilné a l'ahko presídlitel'né. Nároky na ornú pôdu neboli pre nich až tak dôležité. Ked’že základným valašským právom bolo právo pást' valašský dobytok, hlavný význam predstavoval dostatok kvalitných pasienkov. Pre majitel'ov panstiev znamenali na jednej strane zdroj nových príjmov a na druhej strane boli v pohraničných územiach hojne využívaní na vojenskú, strážnu a bezpečnostnú službu. V neskoršom období po viacerých územných sporoch o pasienky a kvôli lepšiemu výberu daní boli títo valasi, ale aj d’alší noví obyvatelia presídl'ovaní do dolín, kde im boli vymedzené presné usadlosti (zárubky). Každá takáto územná jednotka 
predstavovala pás pozemku tiahnuci sa od jedného hrebeňa na hranici chotára $\mathrm{k}$ druhému, vedúci kolmo na dolinu. Vymedzené územie si osadníci museli vyklčovat' a skultivovat'. Z hospodárskeho hl'adiska museli prejst' od pastierstva a salašníctva k pol'nohospodárskej výrobe. Na toto prechodné obdobie boli obyvatelia oslobodení od poddanských dávok. Valašská a predovšetkým kopaničiarska kolonizácia má vel’mi podobné znaky ako vrcholnostredoveká kolonizácia na emfyteutickom (zákupnom) práve. Zemepán poveril lokátora, ktorý sústredil valachov na vymedzené územie. Dozeral na ich podriadenost' príslušnému zemepánovi a zabezpečoval plnenie predpísaných peňažných, naturálnych a robotných povinností (Beňko 1985, 40). Charakteristickým pôdorysným typom takto zakladaných obcí je tzv. vol’ná ret’azová kolonizačná dedina (Fekete 1947, 26). Samotná kopaničiarska usadlost’ - „zárubok“ - mala charakteristické vnútorné členenie. Podl’a chotára obce Oščadnica členenie typického zárubku opísal J. Štika (1960, 366, 367): „Za dvorom a hospodárskymi stavbami je nevel'ká pastvina na výbeh hovädzieho dobytka. Uživali ju všetci podielnici zárubku. Ďalej na obidvoch stranách údolia ležia polia a lúky jednotlivých podielnikov. Nad nimi nájdeme na jednej strane údolia pasienok pre hovädzi dobytok, na druhej strane spoločné pastviny a les. Ďalej sú pastviny pre salaše, ktoré sa rozprestierajú na viacerých zárubkoch.“ Nárastom počtu obyvatel’ov sa zárubky delili až po 1/12, pozdĺžne, v neskoršom období aj priečne. Po vytýčení zárubku sa ako prvý prerúbal úzky pás na hranici zárubku v celej svojej dížke. Zárubkové cesty vznikali už počas fázy klčovania vyčlenenej usadlosti ako komunikačný priestor na transport vyt'aženého dreva k dvorovej časti usadlosti a zároveň ulahčovali pohyb medzi dvorom a extravilánovou častou usadlosti. Daalšie cesty sa formovali pri delení pôvodných celých usadlostí, ale pri niektorých nie je vylúčený ich vznik už vo fáze klčovania pôvodného celého zárubku.

Významným písomným prameňom pre skúmanie novovekého osídlenia Uhorska sú vojenské opisy krajiny, ktoré boli vyhotovené ako príloha k Prvému vojenskému mapovaniu (Klein 2003, 19). Opisy v heslovitej forme podávajú strategické informácie dôležité pre pohyb vojska v krajine (1 - lokalizácia sídla do príslušnej stolice; 2 - vzdialenost' do susedných, vzdialenejších sídel v hodinách; 3 - pevné stavby; 4 - vodstvo; 5 - lesy; 6 - lúky a močiare; 7 - cesty; 8 - okolité vrchy; 9 - poznámky). Podl’a týchto opisov boli sledované cesty zjazdné koňom, prípadne peši (Az első katonai felmérés 2004). Ide však iba o odhad pre potreby dobovej armády. Pre transport materiálu do dvorovej časti usadlosti bol využívaný l’ahký voz/vlečka a využívala sa t’ažná sila hospodárskych zvierat. Rovnako predpokladáme zvážanie celých kmeňov stromov priamo za t’ažným zvierat’om, čo mohlo výrazne urýchlit' erózne procesy.

\section{Archeologický výskum}

Dokumentácia reliktov ciest bola realizovaná vo viacerých etapách. V prvej sa vykonal podrobný terénny prieskum celej trasy stavby D3 a jej širšieho okolia, počas ktorého boli v teréne zistené výrazné relikty úvozových a terasových ciest. Viaceré z nich boli stále využívané (SVR2, 3; CIE1-6, 8; SKA1-3, 5-7). V druhej, kabinetnej fáze sme zistené cesty verifikovali s dostupnými aktuálnymi a historickými kartografickými dielami. Ďalej sme na jednotlivých reliktoch vykonali geodeticko-topografický prieskum. Cesty boli dokumentované GPS prístrojom Leica 900. Každá úvozová cesta bola zameraná $\mathrm{v}$ štyroch líniách, ktoré predstavovali hrany na úrovni vrchu a dna úvozu (obr. 2). V poslednej fáze sme na vybraných reliktoch ciest realizovali zistovacie rezy, ktoré boli situované $\mathrm{v}$ dočasnom zábere stavby. Tie sa vyhotovili zemným strojom, s následným ručným dočistením profilov. Pred samotnými výkopmi sa na niektorých úsekoch úvozov uskutočnil prieskum detekorom kovov, pričom boli získané výlučne recentné nálezy (prevažne domový odpad). Šírka všetkých sond zodpovedala šírke svahovacej lyžice zemného stroja, a to približne 2,5 m. Dížka sond bola vytýčená vždy tak, aby tesne presahovala okraje úvozu. Maximálna híbka výkopov súvisela s dosiahnutím sterilného podložia, kde už samotný zásyp úvozu nezasahoval. Rezy boli vyhíbené predovšetkým v miestach max. híbky úvozu, príp. aj v miestach so zaujímavou anomáliou, napr. pri zdvojenom úvoze (napr. SKA 4; obr. 2). Počet sond v rámci každého úvozu bol preto rôzny, teda od jednej až po tri sondy (tab. 2). Počas výskumu neboli nájdené žiadne hnutel'né archeologické nálezy. Profily boli nakoniec kresbovo a fotograficky zdokumentované (obr. 3). 


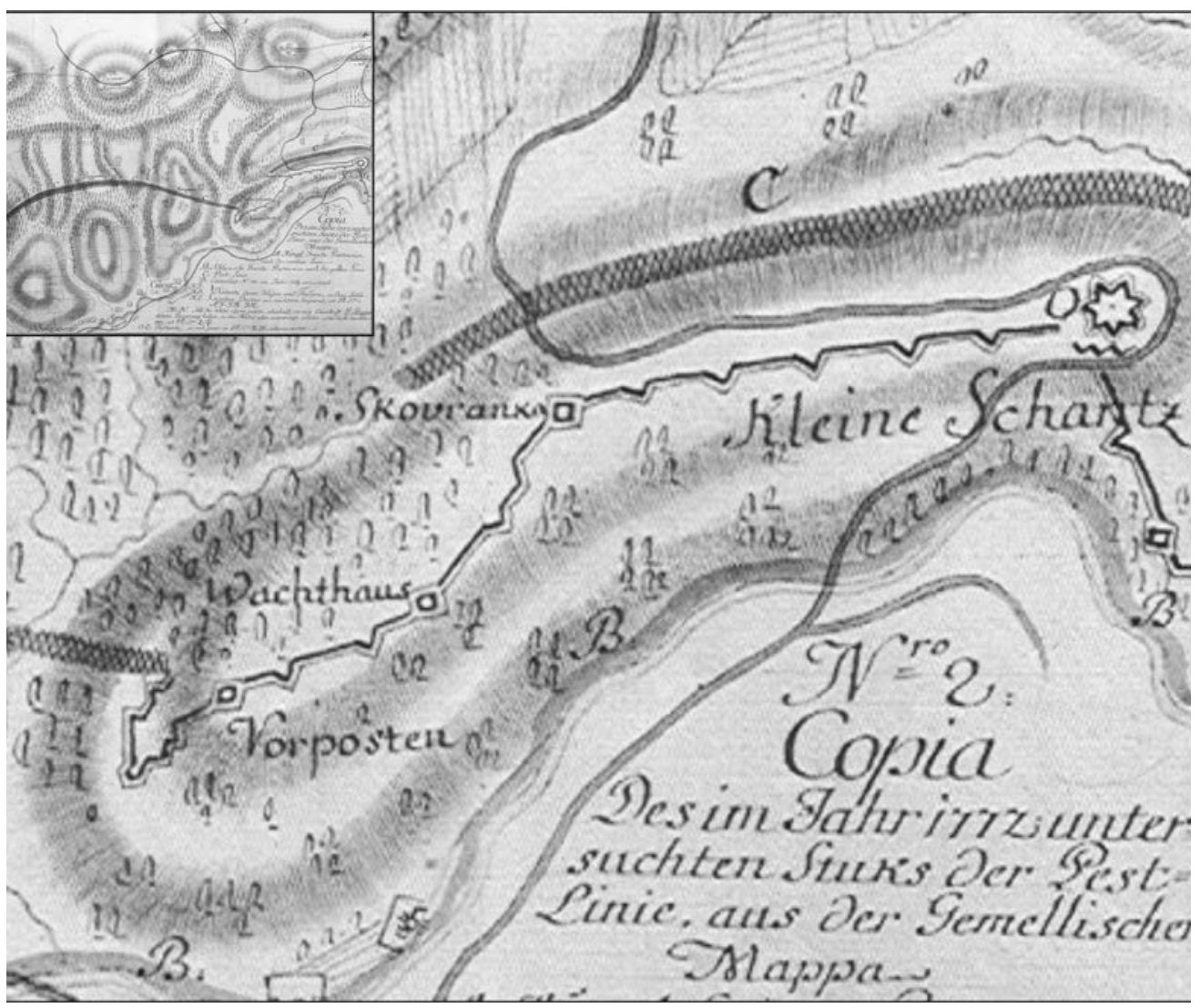

Obr. 2. Ukážka geodetickej dokumentácie reliktov ciest. Cesta SKA4. A-pozdížny profil cesty; B - celkový dokumentovaný priebeh reliktov cesty; C - výrez cesty s lokalizáciou sond v trase stavby D3. a - body namerané GPS; b - zist'ovacie sondy; c-priebeh reliktov cesty; $d$-záber stavby $D 3$.

Abb. 2. Beispiel für die geodätische Dokumentation von Wegerelikten. Weg SKA4. A - Längsprofil des Wegs; B - insgesamt dokumentierter Verlauf des Wegerelikts; C - Wegausschnitt mit Lokalisirung der Sondierungsgrabungen in der Trasse des Baus der Autobahn D3. a - gemessene GPS-Punkte; b - Feststellungsgrabungen; c-Verlauf des Wegerelikts; $d$ - Reichweite des Baus der Autobahn D3. 

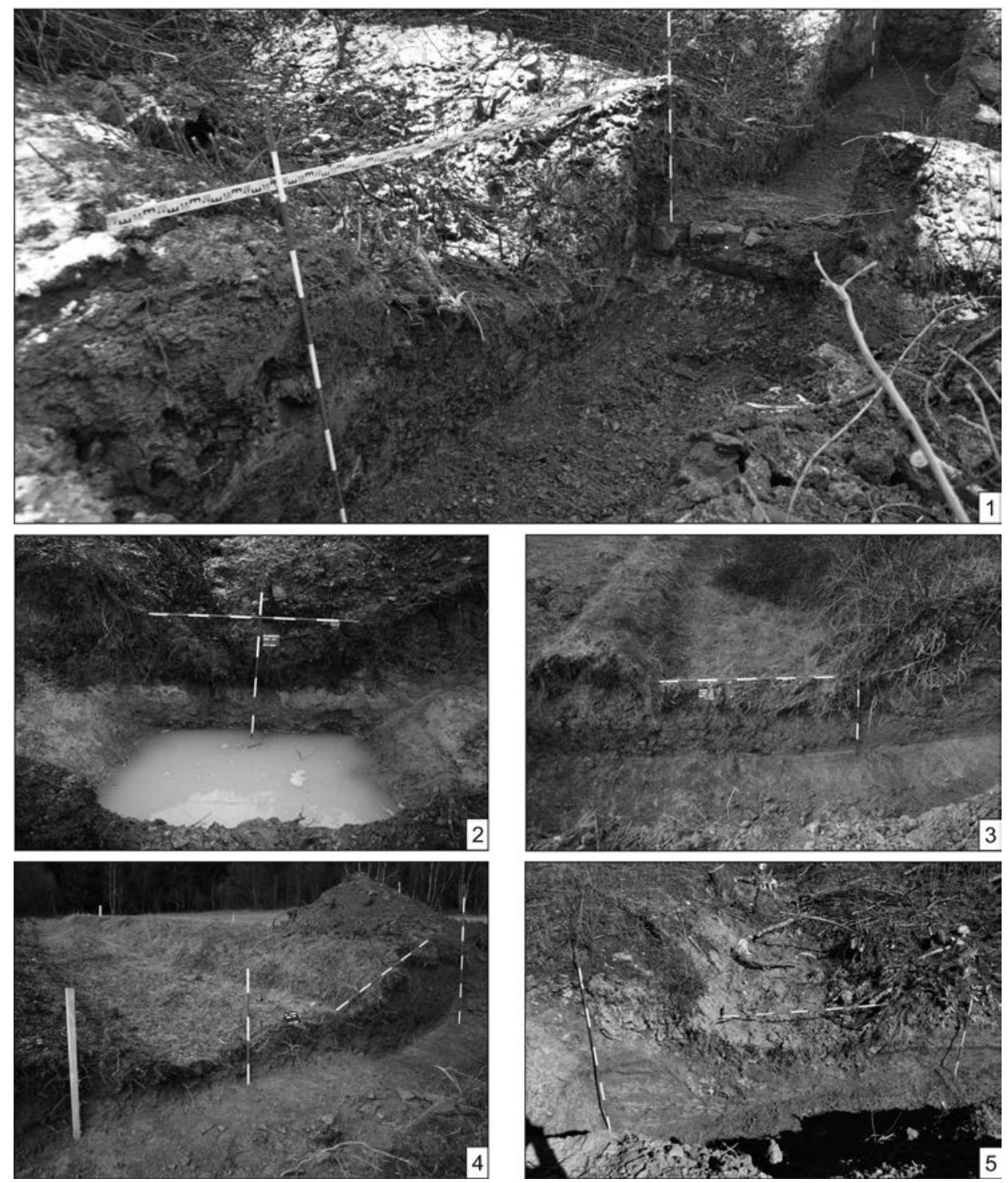

Obr. 3. Fotodokumentácia reliktov ciest. 1 - cesta SKA8; 2 - cesta SVR1, sonda 1; 3 - cesta CIE4, sonda 1; 4 - cesta CIE8, sonda $1 ; 5$ - cesta SKA4, sonda 3.

Abb. 3. Fotodokumentation der Wegerelikte. 1 - Weg SKA8; 2 - Weg SVR1, Sondierungsgrabung 1; 3 - Weg CIE4, Sondierungsgrabung 1; 4 - Weg CIE8, Sondierungsgrabung 1; 5 - Weg SKA4, Sondierungsgrabung 3.

\section{Analýza reliktov (tab. 1; 2)}

Súbor dokumentovaných reliktov obsahuje dve kategórie objektov. Prvú tvorí 15 reliktov ciest, ktoré boli priamo viditel'né $\mathrm{v}$ teréne. Realizovali sa na nich zist'ovacie rezy a podrobná dokumentácia uloženín v trase stavby. Druhú kategóriu tvoria štyri cesty (SVR2; CIE1, 5; CIE6), ktoré boli zretel'né na mapových dielach. Dokumentoval sa ich priebeh, ale v rámci dočasného záberu dial'nice D3 na nich nebolo možné realizovat' zist'ovacie sondy. Z tohto dôvodu sme pri nich nemohli sledovat' všetky parametre. Pri analýze reliktov sme vychádzali z metodických postupov publikovaných v prácach D. Adama (1999; 2004) a J. Martínka a kol. (2013). 


\begin{tabular}{|c|c|c|c|c|c|c|c|}
\hline \multirow[b]{2}{*}{$\begin{array}{l}\text { kód } \\
\text { cesty }\end{array}$} & \multicolumn{3}{|c|}{ morfologické a funkčné parametre } & \multicolumn{4}{|c|}{ metrické parametre v rámci celej sledovanej dížky } \\
\hline & $\begin{array}{l}\text { kategória } \\
\text { cesty }\end{array}$ & terén & tvar & $\begin{array}{l}\text { sklon } \\
\left({ }^{\circ}\right)\end{array}$ & $\begin{array}{l}\text { max svetlá } \\
\text { híbka/sklon } \\
\left(\mathrm{m} /{ }^{\circ}\right)\end{array}$ & $\begin{array}{l}\text { miesto maximálnej } \\
\text { híbky reliktu/ } \\
\text { sklon }\end{array}$ & $\begin{array}{c}\text { max sklon/ } \\
\text { svetlá híbka } \\
(\% / \mathrm{m})\end{array}$ \\
\hline SVR1 & regionálna & chrbát & úvoz & $4-10$ & $2,0 / 4-6$ & uprostred svahu & $8-10 / 1,0$ \\
\hline SVR2 & lokálna & chrbát & nevýrazný relikt & $6-10$ & $\mathrm{x}$ & $\mathrm{x}$ & $\mathrm{x}$ \\
\hline SVR3 & lokálna & chrbát & úvoz & $6-12$ & $2,3 / 6-8$ & uprostred svahu & $10-12 / 2,0$ \\
\hline CIE1 & lokálna & úbočie & terasa & $4-12$ & $\mathrm{x}$ & $\mathrm{x}$ & $\mathrm{x}$ \\
\hline CIE2 & lokálna & chrbát & úvoz & $4-12$ & $3,6 / 4-6$ & úpätie svahu & $10-12 / 1,2$ \\
\hline CIE3 & lokálna & chrbát/vrstevnica & úvoz/terasa & $6-12$ & $1,2 / 6-8$ & uprostred svahu & $10-12 / 0,8$ \\
\hline CIE4 & lokálna & chrbát & úvoz/terasa & $6-14$ & $1,4 / 12-14$ & úpätie svahu & $12-14 / 1,4$ \\
\hline CIE5 & lokálna & chrbát & $\begin{array}{l}\text { úvoz/nevýrazný } \\
\text { relikt }\end{array}$ & $6-12$ & $3,7 / 10-12$ & úpätie svahu & $10-12 / 3,7$ \\
\hline CIE6 & lokálna & chrbát & nevýrarný relikt & $6-10$ & $\mathrm{x}$ & $\mathrm{x}$ & $\mathrm{x}$ \\
\hline CIE7 & lokálna & úbočie & úvoz/terasa & $8-12$ & $2,2 / 10-12$ & uprostred svahu & $10-12 / 2,2$ \\
\hline CIE8 & lokálna & chrbát & terasa & $6-10$ & $2,2 / 6-8$ & uprostred svahu & $8-10 / 0,4$ \\
\hline SKA1 & lokálna & traverz & terasa & $10-18$ & $2,3 / 16-18$ & uprostred svahu & $16-18 / 2,3$ \\
\hline SKA2 & lokálna & chrbát & úvoz & $12-16$ & $1,5 / 12-16$ & úpätie svahu & $14-16 / 1,5$ \\
\hline SKA3 & lokálna & chrbát & $\begin{array}{l}\text { úvoz/nevýrazný } \\
\text { relikt }\end{array}$ & $12-16$ & $3,1 / 14-16$ & úpätie svahu & $14-16 / 3,1$ \\
\hline SKA4 & lokálna & chrbát & úvoz & $10-18$ & $2,2 / 16-18$ & $\begin{array}{l}\text { uprostred svahu; } \\
\quad \text { (sonda 1) }\end{array}$ & $16-18 / 2,2$ \\
\hline SKA5 & lokálna & chrbát & úvoz & $8-14$ & $1,8 / 8-10$ & uprostred svahu & $12-14 / 0,5$ \\
\hline SKA6 & lokálna & chrbát & úvoz & $8-14$ & $1,2 / 10-12$ & uprostred svahu & $12-14 / 1$ \\
\hline SKA7 & lokálna & chrbát & úvoz & $8-12$ & $1,7 / 8-10$ & uprostred svahu & $10-12 / 0,7$ \\
\hline SKA8 & lokálna & chrbát & úvoz & $8-18$ & $3,2 / 16-18$ & $\begin{array}{l}\text { uprostred svahu; } \\
\quad \text { (sonda 1) }\end{array}$ & $16-18 / 3,2$ \\
\hline
\end{tabular}

Tab. 1. Morfologické, funkěné a metrické parametre ciest v rámci celého sledovaného priebehu.

Tab. 1. Morphologische, funktionale und metrische Parameter der Wege im Rahmen des gesamten beobachteten Verlaufs.

Procesy, ktoré vplývali na vznik charakteristických terénnych reliktov boli podmienené zmesou rôznorodých faktorov. Medzi hlavné determinanty radíme:

- rezistenciu podložia,

- sezónnost' využívania cesty,

- lokálne klimatické pomery,

- obdobie existencie cesty,

- intenzitu pohybu,

- typ a hmotnost' dopravných prostriedkov,

- svahovitost' terénu.

V rámci skúmaného súboru reliktov ciest sme vzhl'adom na determinanty sledovali v kategórii celého sledovaného priebehu cesty tieto parametre:

- umiestnenie v teréne (chrbát, vrstevnica, úbočie, traverz),

- tvar reliktu (úvoz, terasa),

- eróziu, resp. sekundárnu úpravu reliktu,

- max. svetlú híbku úvozu vo vzt’ahu k sklonu svahu,

- max. sklon svahu vo vzt’ahu k híbke úvozu. 


\begin{tabular}{|c|c|c|c|c|c|c|}
\hline $\begin{array}{l}\text { kód } \\
\text { cesty }\end{array}$ & sonda & sklon $\left({ }^{\circ}\right)$ & híbka (m) & prerezané pôvodné vrstvy & $\begin{array}{l}\text { sekundárne navrstvené } \\
\text { sedimenty }\end{array}$ & $\begin{array}{c}\text { podložie-dno } \\
\text { úvozu }\end{array}$ \\
\hline SVR1 & 1 & $4-6$ & 1,6 & $\mathrm{~S}+\mathrm{ZP}$ & & I \\
\hline SVR3 & 1 & $8-10$ & 0,6 & $S+Z P$ & & $\mathrm{~S}$ \\
\hline CIE2 & 1 & $10-12$ & 1,2 & $\mathrm{~S}+\mathrm{ZP}$ & & $\mathrm{P}$ \\
\hline CIE3 & 1 & $6-8$ & 1,2 & $\mathrm{~S}+\mathrm{ZP}$ & $\mathrm{TP}$ & $\mathrm{S}+\mathrm{ZP}$ \\
\hline CIE4 & 1 & $8-10$ & 0,8 & $\mathrm{~S}+\mathrm{ZP}(?)$ & & $\mathrm{S}+\mathrm{ZP}(?)$ \\
\hline CIE7 & 1 & $8-10$ & 0,8 & $\mathrm{~S}$ & $\mathrm{~K}, \mathrm{TP}$ & $\mathrm{S}+\mathrm{I}$ \\
\hline CIE8 & 1 & $8-10$ & 0,8 & $\mathrm{~S}$ & $\mathrm{TP}$ & $\mathrm{S}$ \\
\hline SKA1 & 1 & $12-14$ & 0,2 & $\mathrm{~S}+\mathrm{ZP}$ & $\mathrm{K}$ & $\mathrm{ZP}$ \\
\hline SKA2 & 1 & $12-14$ & 0,4 & $\mathrm{~S}+\mathrm{I}$ & $\mathrm{K}$ & I \\
\hline SKA3 & 1 & $12-14$ & 0,4 & $\mathrm{~S}+\mathrm{ZP}$ & & $\mathrm{S}+\mathrm{ZP}$ \\
\hline SKA4 & 1 & $16-18$ & 1,2 & $\mathrm{~S}+\mathrm{ZP}+\mathrm{I}$ & $\mathrm{K}$ & $\mathrm{S}+\mathrm{I}$ \\
\hline SKA4 & 2 & $14-16$ & 1,2 & $\mathrm{~S}+\mathrm{ZP}$ & & $\mathrm{P}$ \\
\hline SKA4 & 3 & $14-16$ & 1,4 & $\mathrm{~S}+\mathrm{ZP}$ & $\mathrm{K}$ & $\mathrm{S}$ \\
\hline SKA5 & 1 & $8-10$ & 1,4 & $\mathrm{~S}+\mathrm{ZP}$ & & $\mathrm{S}+\mathrm{I}+\mathrm{ZP}$ \\
\hline SKA6 & 1 & $10-12$ & 1 & $\mathrm{~S}+\mathrm{ZP}$ & & $\mathrm{S}+\mathrm{I}+\mathrm{ZP}$ \\
\hline SKA7 & 1 & $8-10$ & 1,4 & $\mathrm{~S}+\mathrm{ZP}$ & & $\mathrm{P}$ \\
\hline SKA8 & 1 & $16-18$ & 1,4 & $\mathrm{~S}+\mathrm{ZP}$ & $\mathrm{K}, \mathrm{TP}$ & $\mathrm{ZP}$ \\
\hline SKA8 & 2 & $14-16$ & 0,9 & $\mathrm{~S}+\mathrm{ZP}$ & $\mathrm{K}, \mathrm{TP}$ & $\mathrm{P}$ \\
\hline SKA8 & 3 & $12-14$ & 0,6 & $S+Z P$ & $?$ & $\mathrm{ZP}$ \\
\hline
\end{tabular}

Tab. 2. Metrické parametre a stratigrafická situácia v sondách. I - ílovité podložie; S - hnedá hlina (svahovina?), niekedy s izolovanými kusmi pieskovcov; ZP - zvetraný pieskovec; $P$ - nezvetraný, kompaktný pieskovec; $K$ - umelo nahádzaná vrstva kameňov; TP - umelo navŕšená terasa pol’a.

Tab. 2. Metrische Parameter und stratigraphische Situation in den Sondierschnitten. I - Tonuntergrund; S - brauner Lehm (Gehängelehm?), bisweilen mit isolierten Sandsteinbrocken; ZP - verwitterter Sandstein; P - nicht verwitterter, kompakter Sandstein; K - künstlich angelegte Steinschicht; TP - künstlich angelegte Feldterrasse.

V rámci zistovacích sond sme sledovali:

- typy prerezaných pôvodných geologických uloženín,

- prítomnost'/absenciu sekundárne navrstvených sedimentov,

- typ podložia na úrovni dna úvozu, ktoré zastavilo eróziu.

Skúmané cesty boli v rámci lokálneho terénu vedené zväčša do svahu po chrbte, kolmo na vodné toky formujúce údolie. Ojedinele viedli úbočím, prípadne traverzom, či čiastočne po vrstevnici. Vo všetkých prípadoch môžeme hovorit’ o severojužnej orientácii týchto ciest s miernymi odchýlkami v osi severozápad-juhovýchod.

Z hladiska tvaru dopravného reliktu prevažovali úvozové formy a menej rozvinuté relikty. Pri druhej kategórii je potrebné rátat' aj s možnost'ou, že pôvodný úvozový relikt bol úpravou terénu zasypaný a cesta $\mathrm{v}$ súčasnosti nevykazuje výraznejšie stopy reliktov. Terasové relikty ciest vznikali pôsobením gravitácie na sedimenty, ktoré sa nachádzali v ich bezprostrednej blízkosti. Vznikali dvoma spôsobmi. Bud' zarezávaním sa do úbočia za prirodzeného pôsobenia gravitácie na premiestňujúce sa sedimenty, alebo pohybom sedimentov v súvislosti s obrábaním polí. Väčšina ich vznikla navŕšením terasy pol’a na jednu hranu úvozu (obr. 4:2). Vo viacerých prípadoch evidujeme vrstvy nahádzaných kameňov, čo môže súvisiet’ aj so snahou o opravu komunikácie poškodenej eróziou (obr. 4:1, 4). V jednom prípade bola pravdepodobne do priestoru úvozu umelo navíšená terasa pola, čo spôsobilo posun samotného telesa cesty (obr. 4:3).

Intervaly sklonu konkrétnych ciest sa pohybovali v rozpätí $4-18^{\circ}$. Pozdížny profil mali všetky cesty pozvol’ne stúpajúceho charakteru, bez výraznejších zmien. Odchýlky v hodnotách súviseli s lokálnou konfiguráciou terénu. Cesty s hraničným sklonom pre pohyb dopravným pro- 
striedkom boli dokumentované predovšetkým v katastri Skalitého. Porovnávaním vzt’ahu medzi max. svetlou híbkou reliktu a sklonom cesty v danom mieste sa v celom sledovanom priebehu nepotvrdil všeobecne uvádzaný predpoklad priamej závislosti híbky od vel'kosti sklonu. Miesta s najväčšou híbkou reliktov sme detegovali skôr v priestore s menším sklonom v terasách, ktoré boli vytvorené gravitačným pohybom sedimentov v rámci obrábaných polí. Zistilo sa, že dôležitú úlohu pri tvorbe jednotlivých reliktov zohrávalo geologické podložie.

Stratigrafická situácia zistovacích sond poukazuje na to, že úvozové relikty ciest boli zarezané do vrstiev svahoviny a zvetraného pieskovca. Cesty sa častokrát zarezali až po úroveň kompaktného pieskovca, ktorý zabránil d’alšiemu prehlbovaniu úvozov dopravným pohybom alebo eróziou. Híbka úvozov tak závisela predovšetkým od typu podložia, resp. od toho, ako hlboko sa nachádzala vrstva kompaktného pieskovca. Sklon svahu mal druhoradý význam. Dôležitú úlohu mohol zohrat' v úsekoch s identickým podložím. Poukazuje na to situácia na ceste SKA8 v sondách 1 a 3. Cesta bola zarezaná do rovnako hrubých vrstiev hnedej hliny a zvetraného pieskovca, pričom dno úvozu netvoril kompaktný pieskovec. V prípade sondy 1 , ktorá sa nachádzala v strmšom svahu, bol úvoz zarezaný hlbšie. Naopak, v sonde 3 bol zarezaný plytšie, nakol'ko sa aj nachádzal v miernejšom svahu (tab. 2).

\section{Analýza kartografických prameňov}

Všetky dokumentované relikty ciest sme konfrontovali s dostupnými kartografickými prameňmi. Ked’že ide o cesty lokálneho charakteru, škála dostupných historických máp, ktoré by mohli postihnút' ich priebeh, nie je až taká vel'ká. Mapy s dostatočnou mierkou na vyobrazenie sledovaných ciest, ktoré sme sledovali, boli nasledovné:

Prvé vojenské mapovanie, realizované v rokoch 1763-1785. Oblast' severozápadného Slovenska bola mapovaná medzi prvými v rokoch 1769-1772 (Prikryl 1976, 65). Na tomto mapovaní, prvom vo vel'kej mierke $1: 28800$, sa podarilo identifikovat' predovšetkým pomiestne názvy, ktoré pomohli pri identifikácii pôvodných zárubkov.

Druhé vojenské mapovanie, ktoré sa realizovalo v rokoch 1806-1869. Výhodou tohto mapového diela je možnost' georeferencovania s reálnymi nameranými údajmi z terénu. Mapovanie sme využili na verifikáciu jednotlivých ciest zistených v teréne a spolu s pomiestnymi názvami na identifikovanie historických zárubkov.

Skúmané relikty ciest sme verifikovali na základných mapách 1:10000 a 1:25000 z 50. rokov 20. storočia a historickom ortofotosnímkovaní, ktoré sa realizovalo rovnako v 50. rokoch 20. storočia. Ďalej sme sledovali ich vývoj na aktuálnych základných mapových dielach $1: 10000$ a 1:25000. Všetky dokumentované relikty sú na sledovaných mapách zobrazené. Nie všetky cesty zachytené na mapách však boli potvrdené priamo v teréne. Môžeme to vysvetlit' intenzifikáciou pol'nohospodárstva, úpravou a scel'ovaním ornej pôdy v druhej polovici 20. storočia. Po konfrontácii všetkých dostupných prameňov môžeme povedat', že preskúmané relikty tvoria zmes ciest, ktoré vymedzovali pôvodné usadlosti vyčlenené pri kolonizovaní tohto územia a d’alších ciest predstavujúcich neskorší vývoj ich delenia. Najzretel'nejšia situácia je vyobrazená na historických ortofotosnímkach z 50. rokov 20. storočia. Pri analyzovaní d’alšieho priebehu ciest bolo na mapách v jednom prípade zistené (cesta SVR1), že ide o vetvu regionálnej cesty spájajúcej žilinskú a kysuckú oblast's Těšínskom. Trasa prechádzajúca Jablunkovským priesmykom viedla suchou trasou po návrší, ktoré oddel'uje údolie Milošovského a Šlahorovho potoka. Nachádzala sa v bezprostrednej blízkosti opevnenia Staré šance vo Svrčinovci, ktoré tu boli vybudované v polovici 16. storočia práve kvôli kontrole cesty. Samotná pevnost' porušuje niekol'ko úvozov zo zväzku ciest (Vojteček 2007, 44). Podl'a Prvého vojenského mapovania ide o vetvu krajinskej hradskej, ktorá začínala pri Žiline. Odtial' pokračovala cez Kysucké Nové Mesto, Čadcu cez Staré šance a Nové šance v Mostech u Jablunkova, d’alej do Sliezska. Trasa na listoch Druhého vojenského mapovania stratila význam a nahradila ju údolná trasa popri Šlahorovom potoku. 


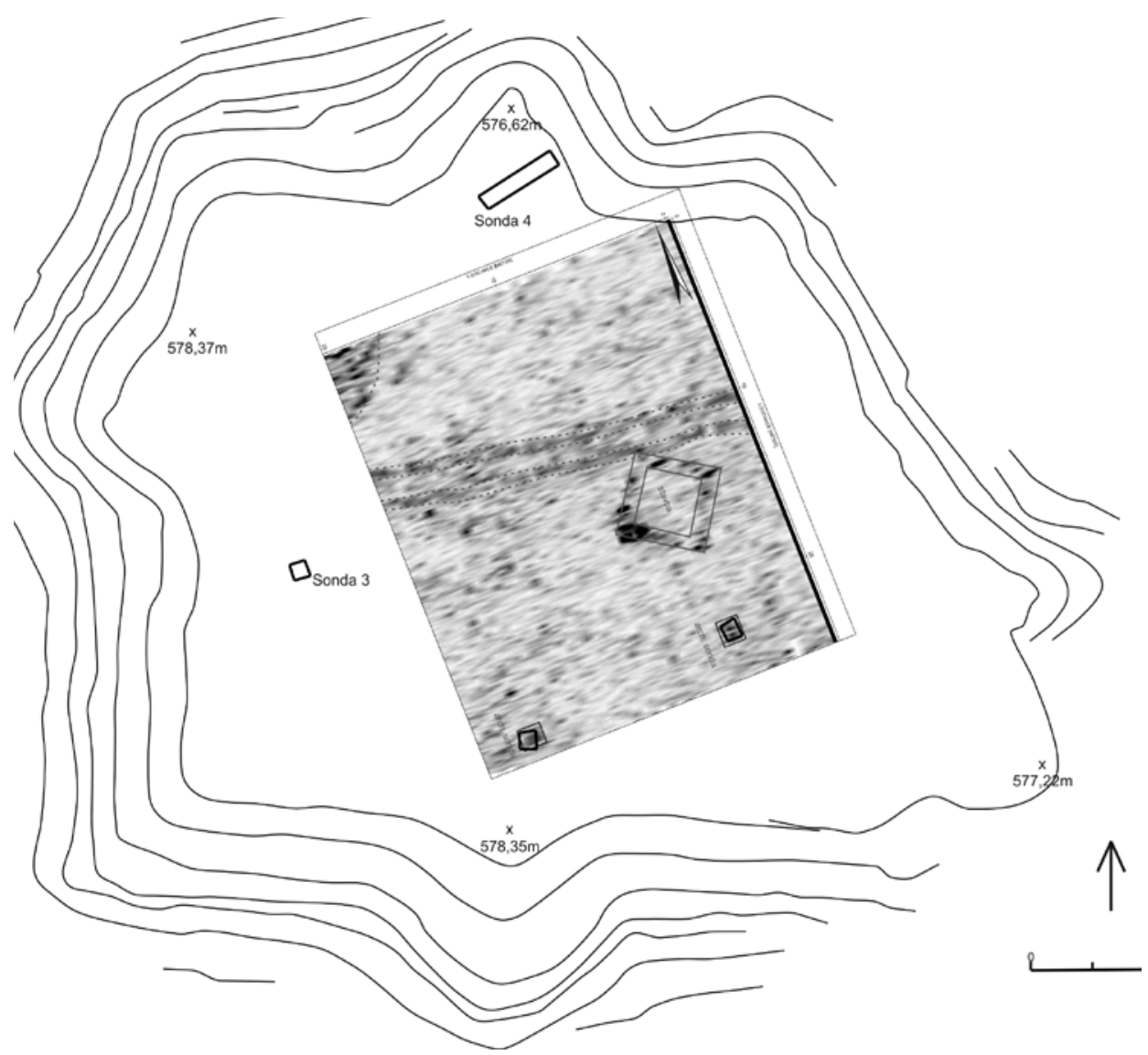

Obr. 4. Vybrané dokumentované profily úvozových ciest. A - humusovitá vrstva; B - zásyp úvozu (vrstva kameňov a hliny); B (?) - pravdepodobný zásyp úvozu (hnedá hlina); C - hnedá hlina s izolovanými kusmi pieskovcov; D - zvetraný pieskovec; E - tmavosivá hlina s izolovanými kusmi pieskovcov; F - sivá ílovitá hlina; G - vrstva nahádzaných kameňov; H - žltohnedá hlina.

Abb. 4. Ausgewählte dokumentierte Hohlwegprofile. A - Humusschicht; B - Verfüllung des Hohlwegs (Stein- und Lehmschicht); B (?) - wahrscheinliche Hohlwegverfüllung (brauner Lehm); C - brauner Lehm mit isolierten Sandsteinbrocken; D - verwitterter Sandstein; E - dunkelgrauer Lehm mit isolierten Sandsteinbrocken; F - grauer tonhaltiger Lehm; G - aufgeworfene Steinschicht; H - gelbbrauner Lehm. 


\section{Analýza historických prameňov}

Medzi základné historické pramene k novovekému osídleniu patria urbáre feudálnych panstiev. Predstavujú súpis poddanského pozemkového majetku a predpis z neho povinných platov, dávok a robôt podl'a richiet, vsí a usadlostí. Urbáre, ako príručky správy, obsahujú unikátne údaje o demografickej a sociálnej štruktúre obyvatel'ov jednotlivých panstiev.

V sledovaných obciach sme porovnávali vývoj osídlenia a delenia vyčlenených usadlostí v rámci dvoch urbárov hradného panstva Strečno, ktorému dediny Čierne, Skalité a Svrčinovec prislúchali. Prvý je urbár hradného panstva Strečno z roku 1662, ktorý na vydanie pripravil J. Sopko. V urbári boli obce Čierne a Skalité ešte v lehote bez povinnosti odvádzat' poddanské dávky. Druhý urbár hradného panstva Strečno je z roku 1712 a predstavuje čast' panstva Pavla Esterházyho. Na vydanie ho pripravil L. Juck. Obidva urbáre sú publikované ako príloha práce R. Bednárika (1967) o l’udovom stavitel'stve na Kysuciach. Kým v roku 1662 v sledovaných obciach prevládajú celé a polovičné usadlosti (pri obci Čierne sú iba mená obyvatel’ov, bez príslušnej čiastky), o 50 rokov už vidíme výrazné delenie, kde prevládajú $1 / 3$ a predovšetkým 1/4 čiastky. Začínajú sa objavovat' čiastky až do $1 / 8$ celého zárubku, pričom v neskoršom období neboli výnimkou usadlosti o vel'kosti $1 / 12$ celej usadlosti (obr. 5-7). Pre porovnanie sme sledovali niektoré vybrané údaje z d’alších prameňov. V urbári panstva Budatín z roku 1658 sa pri obci Svrčinovec spomína iba šest' valachov (Marsina-Kušík 1959, 300). Podl’a dvoch publikovaných súpisov hradného panstva Strečno z rokov 1696 a 1705 je obec Svrčinovec rozdelená na 18 zárubkov. Obce Čierne a Svrčinovec sú rozdelené na 30 zárubkov (tab. 3).

Podl'a názvov zárubkov a osobných mien nachádzajúcich sa $\mathrm{v}$ sledovaných urbároch môžeme načrtnút' vývoj dedenia, ako aj samotného delenia usadlostí na viacerých konkrétnych príkladoch. V Svrčinovci držia podl'a urbára z roku 1662 Joannes a Mathias Kuffa každý po jednom polzárubku. V urbári z roku 1712 sa už spomína zárubok Kufovska, ktorý je rozdelený na štyri 1/4 čiastky. Vo Svrčinovci drží podl'a urbára z roku 1662 Joannes Gorelnyk jeden celý zárubok. O 50 rokov neskôr už evidujeme na Gorelnikovskom zárubku štyri čiastky o vel'kosti $1 / 4$. Rovnako však existujú aj prípady, ked' sa pôvodný zárubok nedelil. V roku 1662 držal Joannes Ruczkowecz celý zárubok a rovnako $\mathrm{v}$ roku 1712 evidujeme Ruczkovszki zárubok s jedným majitel’om, ktorý bol držitel'om celého podielu.

\begin{tabular}{|c|c|c|}
\hline obec (urbár) & Zárubky & Hlavy rodín \\
\hline Svrčinovec (1658) & $?$ & 6 \\
\hline Svrčinovec (1662) & $?$ & 17 \\
\hline Svrčinovec (1696) & 18 & $?$ \\
\hline Svrčinovec (1705) & 18 & $?$ \\
\hline Svrčinovec (1712) & 18 & 61 \\
\hline Čierne (1662) & $?$ & 27 \\
\hline Čierne (1696) & 30 & $?$ \\
\hline Čierne (1705) & 30 & 92 \\
\hline Čierne (1712) & 26 & 41 \\
\hline Skalité (1662) & $?$ & $?$ \\
\hline Skalité (1696) & 30 & $?$ \\
\hline Skalité (1705) & 30 & 120 \\
\hline Skalité (1712) & 30 & $?$ \\
\hline
\end{tabular}

Tab. 3. Počet usadlostí (zárubkov) a „hláv rodín“ v sledovaných obciach.

Tab. 3. Anzahl der Anwesen (Hufen) und der „Köpfe der

Familien" in den untersuchten Gemeinden.

\section{Rekonštrukcia zárubkov a ich ciest}

Konfrontácia údajov z jednotlivých urbárov s pomiestnymi názvami a vyobrazenými cestami na historických mapovaniach priniesla zhodné údaje, ktoré umožňovali rekonštrukciu pôvodných zárubkov a ich d’alší vývoj. Prekrytie preskúmaných reliktov ciest s historickými mapami takisto prinieslo očakávané zhody. Ked’že sme pracovali iba s konkrétnym výrezom krajiny, ktorý nedosahoval celé katastre obcí, existenciu a neskoršie delenie zárubkov sa nám bezpečne podarilo identifikovat' $\mathrm{v}$ troch modelových príkladoch. 
Svrčinovec - delenie zárubkov

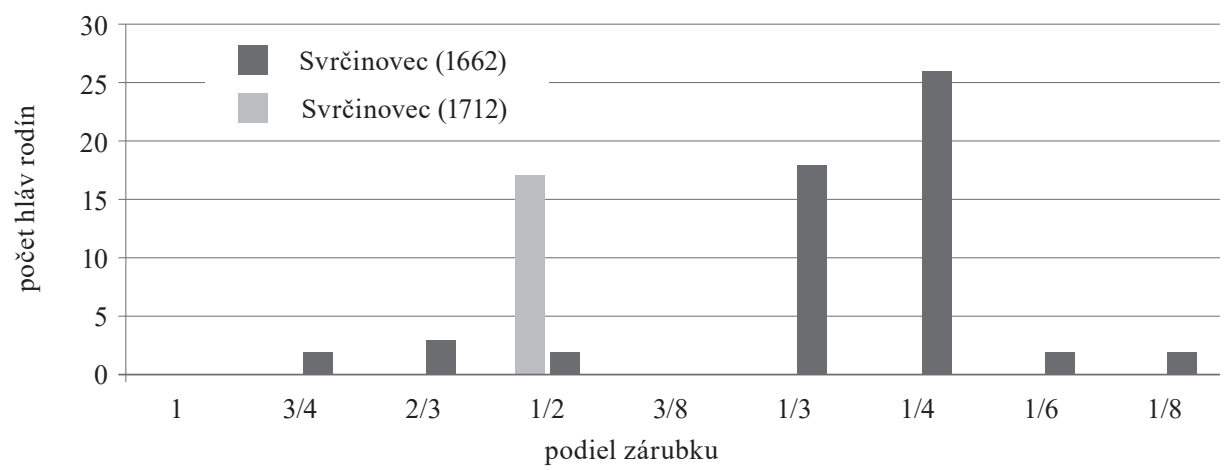

Obr. 5. Svrčinovec. Delenie zárubkov podl'a urbárov panstva Strečno z rokov 1662 a 1712.

Abb. 5. Svrčinovec. Unterteilung der Hufen gemäß dem Urbarium der Herrschaft Strečno aus den Jahren 1662 und 1712.

Čierne (1712)

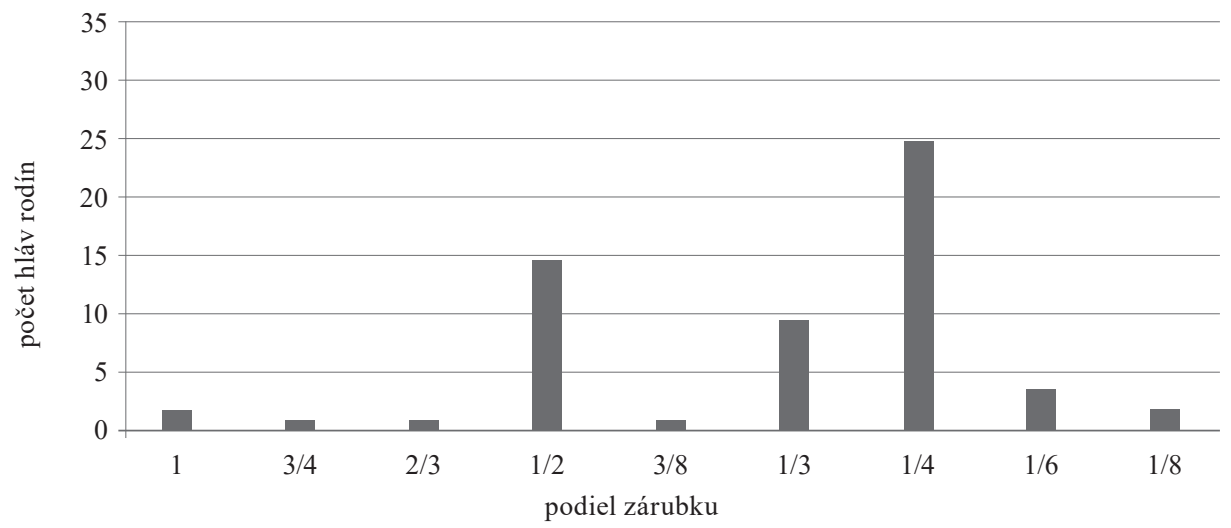

Obr. 6. Čierne. Delenie zárubkov podl’a urbára panstva Strečno z roku 1712.

Abb. 6. Čierne. Unterteilung der Hufen gemäß dem Urbarium der Herrschaft Strečno aus dem Jahr 1712.

Skalité - delenie zárubkov

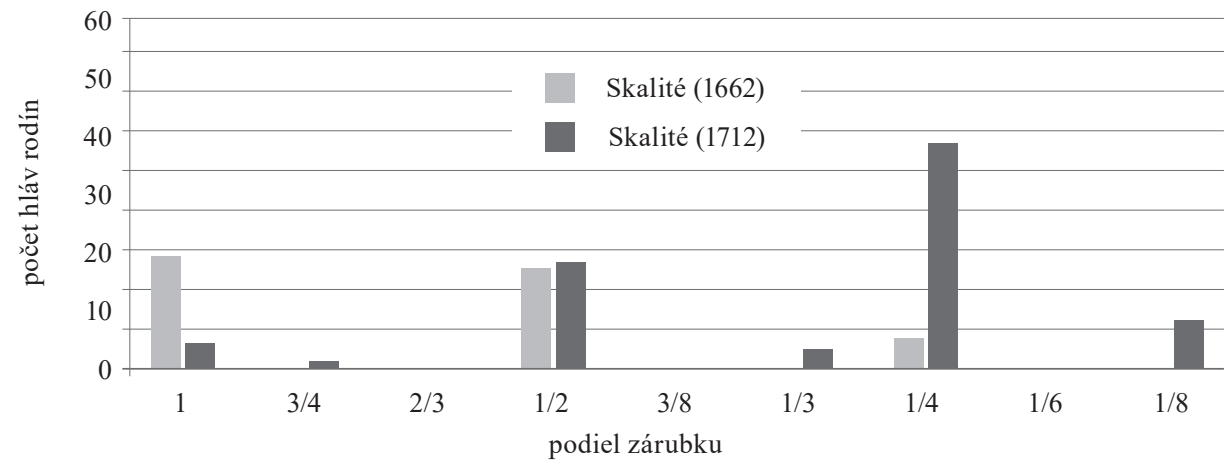

Obr. 7. Skalité. Delenie zárubkov podl’a urbárov panstva Strečno z rokov 1662 a 1712.

Abb. 7. Skalité. Unterteilung der Hufen gemäß dem Urbarium der Herrschaft Strečno aus den Jahren 1662 und 1712. 


\section{Príklad 1: Markov zárubok (obr. 8)}

Markov zárubok je evidovaný v urbári Strečnianskeho panstva z roku 1712, podl’a ktorého na ňom hospodária dvaja podielnici s čiastkami $1 / 2$ a $1 / 2$. Podl'a pomiestnych názvov na Prvom a Druhom vojenskom mapovaní a neskorších mapových dielach sa rozprestieral v oblasti, kde sme dokumentovali cesty CIE1 a CIE2 v katastri obce Čierne. Na Prvom vojenskom mapovaní je označený ako Markow Grund. V mladších mapových dielach sa spomína pomiestny názov Markov a na jeho východnom okraji tečie v osi zárubku Markov potok. Cesta CIE1 vymedzovala hranicu Markovho zárubku zo západnej strany. Cesta CIE2 pravdepodobne súvisela s pozdížnym delením Markovho zárubku na polovicu. Na Druhom vojenskom mapovaní je zretel’né aj delenie, kde sú medzi cestou CIE1 a CIE2 viditel'né d'alšie dve cesty, ktoré sa však do súčasnosti nezachovali.

\section{Príklad 2: Zárubok Grochalowska a Kuzmovszka (obr. 9)}

Prebiehal bezprostredne východne od predchádzajúceho Markovho zárubku, za Markovým potokom. V urbári z roku 1662 sa spomína Andreas Grochal. V urbári z roku 1712 je už Grochalowsky zárubok rozdelený v pomere 3/4 a 1/4. Podl’a pomiestnych názvov na Druhom vojenskom mapovaní (Grochalow) a neskorších mapových dielach sa rozprestieral v priestore, kde sme dokumentovali cesty CIE3 a CIE4. Obidve cesty pravdepodobne súviseli s neskorším delením pôvodného zárubku. Už na vojenskom mapovaní je niekol'ko ciest, z ktorých sa viaceré vôbec nezachovali. Na Druhom vojenskom mapovaní sa v priestore nachádza aj pomiestny názov Kuzmow. Zárubok Kuzmovszka je spomínaný v urbári z roku 1712 hned’ za Grochalowským. Je rozdelený na čiastky 1/2, 1/4, 1/4. Hned' za nimi je spomínaná Altera Kuzmovszka s rovnakými podielmi 1/2, 1/4, 1/4. Na úseku medzi Markovým potokom a Čiernym potokom (na 1. Vojenskom mapovaní označenie Czerna dolina Hobanzow gr.) prebiehali minimálne dva samostatné zárubky.

\section{Príklad 3: Zárubok Koczurowszka (obr. 10)}

Zárubok Koczurowszka v katastri obce Skalité je evidovaný v urbári z roku 1712, kde na ňom hospodária štyria podielnici s rovnakými čiastkami $1 / 4$ usadlosti. Porovnávaním pomiestnych názvov na neskorších mapových dielach z 20. storočia sa rozprestieral v priestore, kde sme dokumentovali cestu SKA8. Tá pravdepodobne vymedzovala západnú hranicu zárubku Koczurowszka.

Pri ostatných dokumentovaných cestách sa nám nepodarilo ich stotožnenie s konkrétnymi zárubkami, avšak pri niektorých môžeme s najväčšou pravdepodobnost'ou predpokladat', že tvoria hranice zárubkov (cesty CIE6; SKA1, 3). Porovnávaním viacerých mapových podkladov sa môžeme rovnako domnievat', že v niektorých prípadoch sa vyvinuli na existujúce asfaltové prístupové cesty k jednotlivým domom súčasného ulicového systému obcí. Vel'kost' konkrétneho zárubku závisela od konkrétnych prírodných determinantov a možností krajiny. Preto mohli mat' dva vedl'a seba ležiace zárubky rôznu šírku, ked’že dížka bola stanovená hranicou chotára v osi kolmej na vodný tok. Vychádzajúc z dížky chotára v osi vodného toku a počtu historických zárubkov predpokladáme šírku takýchto pásov na úrovni 200-600m.

\section{Záver}

Impulzom pre hlbšie skúmanie reliktov zaniknutých ciest na severných Kysuciach bol záchranný archeologický výskum na trase dial'nice D3 Svrčinovec - Skalité. Už počas terénnej časti výskumu, kedy sa dokumentovali výrazné relikty ciest, bolo evidentné ich pravidelné rozloženie a jednotná orientácia. Dokumentované cesty mali lokálny charakter a až na jeden prípad začínali aj končili v jednom chotári. Snaha o interpretáciu tejto skutočnosti nás doviedla až 


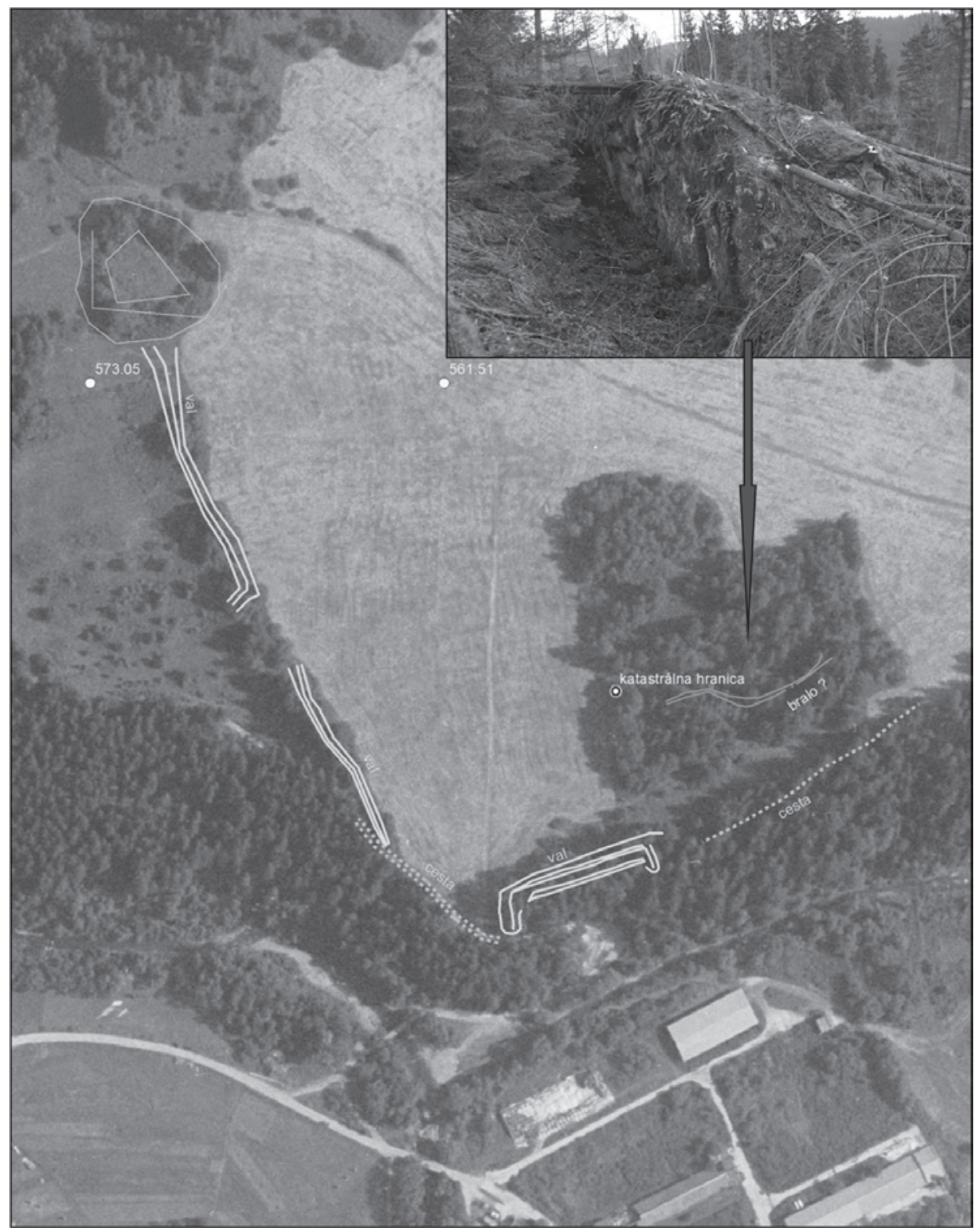

Obr. 8. Čierne - Markov zárubok. 1 - rekonštrukcia na Prvom vojenskom mapovaní; 2 - rekonštrukcia na Druhom vojenskom mapovaní; 3 - rekonštrukcia na historickej ortofotomape (Historická ortofotomapa @ GEODIS SLOVAKIA, s.r.o. a Historické LMS @ Topografický ústav Banská Bystrica); 4 - rekonštrukcia na aktuálnej mape 1 : 10000.

Abb. 8. Čierne - Hufe Markov. 1 - Rekonstruktion auf der Ersten militärischen Kartierung; 2 - Rekonstruktion auf der Zweiten militärischen Kartierung; 3 - Rekonstruktion auf einer historischen Orthofotokarte (Historische Orthofotokarte (C) GEODIS SLOVAKIA, s.r.o." und "Historisches LMS ® Topographisches Institut Banská Bystrica); 4 - Rekonstruktion auf einer aktuellen Karte $1: 10000$. 


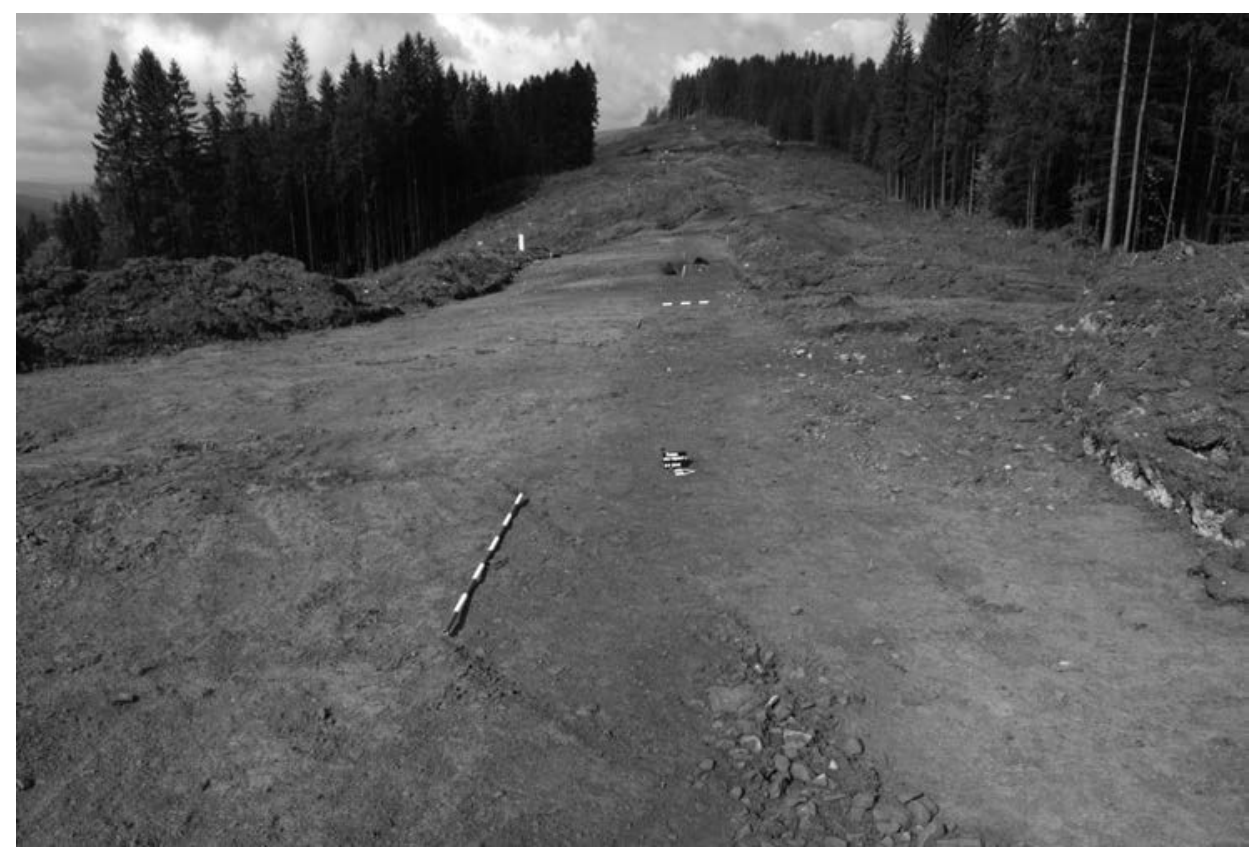

Obr. 9. Čierne - Zárubok Grochalowska. 1 - rekonštrukcia na Prvom vojenskom mapovaní; 2 - rekonštrukcia na Druhom vojenskom mapovaní; 3 - rekonštrukcia na historickej ortofotomape (Historická ortofotomapa @ GEODIS SLOVAKIA, s.r.o. a Historické LMS @ Topografický ústav Banská Bystrica); 4 - rekonštrukcia na aktuálnej mape 1 : 10000.

Abb. 9. Čierne - Hufe Grochalowska. 1 - Rekonstruktion auf der Ersten militärischen Kartierung; 2 - Rekonstruktion auf der Zweiten militärischen Kartierung; 3 - Rekonstruktion auf einer historischen Orthofotokarte (Historische Orthofotokarte @ GEODIS SLOVAKIA, s.r.o. und Historisches LMS @ Topographisches Institut Banská Bystrica); 4 - Rekonstruktion auf einer aktuellen Karte $1: 10000$. 


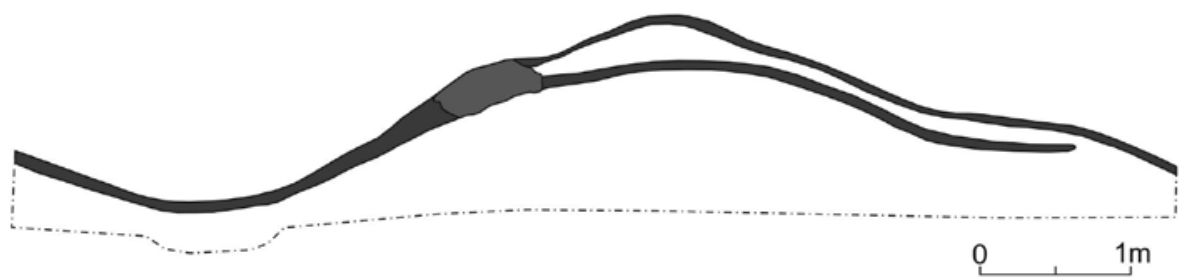

Obr. 10. Skalité - Zárubok Koczurkowska. 1 - rekonštrukcia na Prvom vojenskom mapovaní; 2 - rekonštrukcia na Druhom vojenskom mapovaní; 3 - rekonštrukcia na historickej ortofotomape (Historická ortofotomapa @ GEODIS SLOVAKIA, s.r.o. a Historické LMS @ Topografický ústav Banská Bystrica); 4 - rekonštrukcia na aktuálnej mape $1: 10000$.

Abb. 10. Skalité - Hufe Koczurkowska. 1 - Rekonstruktion auf der Ersten militärischen Kartierung; 2 - Rekonstruktion auf der Zweiten militärischen Kartierung; 3 - Rekonstruktion auf einer historischen Orthofotokarte (Historische Orthofotokarte @ GEODIS SLOVAKIA, s.r.o. und Historisches LMS (c) Topographisches Institut Banská Bystrica); 4 - Rekonstruktion auf einer aktuellen Karte $1: 10000$. 
k problematike kopaničiarskej kolonizácie tohto územia a jej vplyvu na formovanie tradičnej kultúrnej krajiny. Predložený príspevok je však nutné považovat' za prvý krok a vstup do problematiky, ktorej komplexné riešenie vyžaduje medziodborový prístup.

Po konfrontácii všetkých dostupných prameňov môžeme skonštatovat', že skúmané cesty tvorili zmes zárubkových ciest, ktoré vymedzovali pôvodné usadlosti vyčlenené pri kolonizovaní tohto územia a d’alších ciest predstavujúcich neskorší vývoj delenia pôvodných zárubkov. V jednom prípade ide o regionálnu cestu spájajúcu žilinskú a kysuckú oblast' s Těšínskom (cesta SVR1). Najzretel'nejšia situácia je vyobrazená na historických ortofotosnímkach z 50. rokov 20. storočia. Otázky datovania reliktov nie sú až tak podstatné, ked’že ide o objekty s dlhou dobou využívania. Základná os zárubkových ciest sa vyvinula už v priebehu prvej polovice 17. storočia. Cesty, ktoré delili jednotlivé zárubky na menšie čiastky, sa začali formovat' pomerne skoro. Do začiatku 19. storočia predpokladáme existenciu všetkých ciest, ktoré sme v teréne skúmali. Na ich súčasný stav malo vplyv viacero faktorov. Zistilo sa, že na tvorbu jednotlivých reliktov malo najväčší vplyv geologické podložie. Sklon svahu zohrával ovel'a menšiu úlohu. Híbka úvozov bola do vel'kej miery ovplyvnená aj postdepozičnými procesmi, ktoré súviseli predovšetkým s gravitačným pohybom sedimentov v súvislosti s obrábaním polí. Predložená práca poukazuje na dôležitost' zistovacej sondáže v rámci výskumu reliktov zaniknutých ciest. Len vd’aka nej je možné zamerat' sa komplexnejšie na procesy vzniku a zanikania skúmaných ciest, ktoré počas povrchových prieskumov nie je možné postihnút'.

Príspevok vznikol v rámci grantu APVV-15-0330 Človek a krajina na Kysuciach a prillahlom Považí v stredoveku a na začiatku novoveku - Human and landscape in Kysuce and adjacent Považie region in middle ages and beginning of modern age.

\section{Literatúra}

ADAM, D., 1999: Rekonstrukce průběhu starých komunikací - návrh postupu práce a metodiky. Staré stezky 4, 77-82.

- 2004: Staré stezky na Ivančicku. Doktorská disertační práce. Brno.

AZ ELSŐ KATONAI FELMÉRÉS, 2004: Az első katonai felmérés. A Magyar Királyság teljes területe 965 nagyfelbontású térképszelvényen 1782-1785 (DVD-ROM). Arcanum Kiadó. Budapest.

BEDNÁRIK, R., 1967: L’udové stavitel'stvo na Kysuciach. Bratislava.

BEŇKO, J., 1985: Osídlenie severného Slovenska. Košice.

BOLINA, P., 2004: „Per transversum montis Scalicze“ - k interpretaci pozůstatků starých cest na katastru Dolan u Olomouce ve světle rozhraničovací dohody dolanského kláštera a olomoucké kapituly z roku 1404 - „Per transversum montis Scalicze“ - zur Interpretation der Überreste der alten Wege auf dem Kataster der Gemeinde Dolany bei Olomouc [Olmütz] im Lichte der Abgrenzungvereinbarung des Klosters in Dolany und des Kapitels in Olomouc aus dem Jahr 1404, AH 29, 93-118.

BOLINA, P.-CENDELÍN, D., 2011: Úloha hradů Lukov a Brumov v systému komunikací východní Moravy - Die Rolle der Burgen Lukov und Brumov im Verkehrswegesystem Ostmährens, AH 36, 87-108.

CENDELÍN, D.-BOLINA, P.-ADAM, D., 2010: Jevíčko na cestě z Prahy do Olomouce v období raného středověku. Jevíčko.

FEKETE, Š., 1947: Typy vidieckeho osídlenia na Slovensku. Bratislava.

JAVORSKÝ, F., 1978: Výskumy a prieskumy výskumnej expedície Spiš v okrese Spišská Nová Ves - Grabungen und Geländebegehungen der Grabungsexpedition Spiš im Bezirk Spišská Nová Ves. In: AVANS 1978, 103-120. Nitra.

KLEIN, B., 2003: Významné mestá Slovenska na tajných mapách 18. storočia - Bedeutende Städte der Slowakei auf den geheimen Landkarten des 18. Jahrhunderts. Bratislava.

KRŠKA, J.-VELIČKA, D., 2011: Hydronymia povodia Kysuce. Banská Bystrica.

MARSINA, R.-KUŠÍK, M., 1959: Urbáre feudálnych panstiev na Slovensku II. (XVII. storočie). Bratislava.

MARTÍNEK, J. a kol., 2013: Moderní metody identifikace a popisu historických cest. Metodická př́ručka. Brno.

PARÁČOVÁ, A., 2008: Z histórie uhorsko-sliezskych sporov o štátnu hranicu. In: "Šance - Valy: common Heritage", 10-11. C̆adca. 
PAŽINOVÁ, N.-BELJAK, J.-SLÁMOVÁ, M.-BELÁČEK, B., 2013: Stredoveká cestná siet’ v okolí Zvolenského Pustého hradu. Analýza na základe antropogénnych reliéfnych foriem - Mittelalterliches Straßennetz in der Umgebung von Pustý hrad (Wüste Burg) von Zvolen. Analyse auf Grundlage von anthropogenen Reliefformen, ŠZ AÚ SAV 54, 153-170.

SADOWSKA-TOPOR, J., 1999: Starożytne drogi w dolinie rzeki Dzierzgoń w świetle badań archeologicznych. Warszawa.

SLIVKA, M., 1990: Stredoveká cestná siet’ na východnom Slovensku a jej determinanty - Das mittelalterliche Strassennetz in der Ostslowakei und seine Determinanten, Slovenská numizmatika XI., 83-112.

- 1998: Rekonštrukcia cestnej siete na Slovensku (Súčasný stav bádania a jeho perspektívy) - Rekonstruktion des Wegenetzes in der Slowakei (Der gegenwärtige Stand der Forschung und seine Perspektiven), AH 23, 259-275.

ŠTIKA, J., 1960: Salašnictví v považské a kysucké oblasti - Almenwirtschaft im Gebiete der Flüsse Váh und Kysuca, Slovenský národopis VIII, 323-370.

VOJTEČEK, M., 2007: Cesty a komunikácie v žilinskom a kysuckom regióne vo vrcholnom a neskorom stredoveku. Nepublikovaná diplomová práca ulož. na Katedre archeológie FF UKF v Nitre.

\section{Zusammenfassung}

Dokumentation der untergegangenen Wege im Katastergebiet der Gemeinden Svrčinovec, Čierne und Skalité. Eine Skizzierung der Problematik der Rodungskolonisation im nördlichen Teil der Region Kysuce.

Die durchgeführten Untersuchungen und die Dokumentation untergegangener Relikte der Kulturlandschaft in der Region Kysuce wurden durch den Bau des Autobahnabschnitts D3 Svrčinovec - Skalité hervorgerufen. Die untersuchte Trasse führte durch die Katastergebiete der Gemeinden Svrčinovec, Čierne und Skalité. Das bergige und waldbedeckte Gelände der Landschaft hat sich positiv auf die Erhaltung der charakteristischen Relikte untergegangener Wege ausgewirkt. Neunzehn dokumentierte Hohlwegrelikte stellen in der Slowakei den bislang größten untersuchten in sich geschlossenen Komplex dar. Im Rahmen einer summarischen Auswertung haben wir uns auf metrische, morphologische und funktionale Merkmale sowie auf die Frage der Entstehungmechanismen der Hohlwege konzentriert. Das Niveau der Eintiefung in das ursprüngliche Gelände bewegte sich im Intervall zwischen 0,2-3,7 m. Da der Einschnitt eines Hohlwegs in das umliegende Gelände von verschiedenen Faktoren abhängt, gilt bei keinem Fall, dass zwischen seiner Größe und dem Alter des Weges ein direkt proportionales Verhältnis besteht. In allen Fällen kann man von einer Nord-Süd-Orientierung dieser Wege mit leichter Abweichung in der Achse Nordwest-Südost sprechen. Die Orientierung hing mit dem Verlauf der Rodungskolonisation zusammen, die sich in einem charakteristischen Grundrisstyp der Besiedelung niederschlug, den man als „offenes kolonistisches Kettendorf“ bezeichnen kann. Bei der Gründung von Rodungssiedlungen wurde ihre abgesteckte Dorfflur in genaue Teile aufgeteilt. Diese Teile (sog. Zárubky, im Sg. Zárubok, entspricht einer Hufe) zeichneten sich dadurch aus, dass ein Siedler ein zusammenhängendes Stück Land erhielt, das einen Flurstreifen einnahm, der von einem Ende der Dorfflur bis zum anderen reichte. Die Hufengrenzen wurden durch Hufenwege abgegrenzt. Durch einen Anstieg der Einwohner wurden sie dann weiter in kleinere Teile unterteilt, die bis zu 1/12 der ursprünglichen Hufengröße umfassten. Die Wege auf der einen Seite bildeten die Grenze der einzelnen Hufen, auf der anderen Seite gewährleisteten sie den Verkehr und den Transport von Material zwischen den im Außenbereich der Liegenschaft befindlichen Höfen. Bis auf einen Fall hatten alle Hohlwege den Charakter von lokalen Wegen. Der Weg SVR1 stellt laut der Ersten militärischen Kartierung einen Zweig der Haupttrassen durch den Jablunka-Pass dar. Diese Gebirgstrasse verlief neben der Festung Alte Schanze zur Großen Schanze in Mosty bei Jablunkau. Die Befestigungsanlage Alte Schanze in Svrčinovec überdeckt einen Teil der durch diesen Raum führenden Hohlwege, was belegt, dass dort bereits vor dem Bau der Festung in der zweiten Hälfte des 16. Jahrhunderts ein Verkehrsweg existierte. Ab dem Beginn des 19. Jahrhunderts verlor dieser Weg auf Kosten eines im Tal des Bachs 
Šlahorov potok neu angelegten Verkehrswegs an Bedeutung. Bei der zeitlichen Bestimmung der Wegerelikte können wir uns lediglich auf kartographische Quellen stützen, da während der Grabung keine Gegenstände von chronologischer Sensibilität gefunden worden sind. Die Kartenunterlagen belegen jedoch nur für die Entstehungszeit des Werks die Existenz eines Weges. Die Grundachse der Hufenwege hat sich bereits in der ersten Hälfte des 17. Jahrhunderts herausgebildet. Wege, welche die einzelnen Hufen in kleinere Teile unterteilten, begannen sich relativ früh zu formen, und wir vermuten, dass alle von uns im Gelände untersuchten Wege bis zum Beginn des 19. Jahrhunderts bereits existiert haben.

Der vorliegende Beitrag entstand im Rahmen des Förderprojekts APVV-15-0330. Mensch und Landschaft in der Region Kysuce und im benachbarten Waagtal im Mittelalter und zu Beginn der Neuzeit - Human and landscape in Kysuce and adjacent Považie region in middle ages and beginning of modern age.

Mgr. Marek Vojteček, PhD., Archeologický ústav SAV, Akademická 2, 94901 Nitra, Slovenská republika, marek.vojtecek@savba.sk

Mgr. Adrián Nemergut, PhD., Archeologický ústav SAV, Akademická 2, 94901 Nitra, Slovenská

republika, adrian.nemergut@savba.sk 